\title{
Research Article \\ Effects of different doses of Plant-Growth-Promoting Rhizobacteria (PGPR) granules on wheat yield
}

\author{
Sabina Devkota ${ }^{1 *}$, Kamana Rayamajhi ${ }^{1}$, Dil Raj Yadav ${ }^{2}$ and Jiban Shrestha ${ }^{3}$ \\ ${ }^{1}$ Nepal Agricultural Research Council, National Soil Science Research Centre \\ Khumaltar, Lalitpur, Nepal \\ ${ }^{2}$ Agricultural Research Station, Belachapi, Dhanusha, Nepal \\ ${ }^{3}$ National Plant Breeding and Genetics Research Centre, Khumaltar, Lalitpur, Nepal \\ *Correspondence: sabina.devkota@gmail.com \\ *ORCID: https://orcid.org/0000-0002-6557-4916
}

Received: July 25, 2020; Accepted: September 25, 2020; Published: October 30, 2020

(C) Copyright: Devkota et al. (2020).

\begin{abstract}
(c) (1) Th This work is licensed under a Creative Commons Attribution-Non Commercial 4.0 International License.
\end{abstract}

\begin{abstract}
Plant growth promoting rhizobacteria (PGPR) are the soil bacteria inhabiting around/on the root surface and are directly or indirectly involved in promoting plant growth and development. This study was conducted at research field of Agriculture Research Station, Belachapi, Dhanusa, Nepal in 2018 to identify the effects of PGPR on wheat production. The experiment was laid out in Randomized Complete Block Design with three replications. Eight treatments namely, T1: Control; T2: Recommended doses of fertilizers (RDF) (100:50:50 N: $\mathrm{P}_{2} \mathrm{O}_{5}: \mathrm{K}_{2} \mathrm{O}$ kg/ha); T3:10 t/ha Farm Yard Manure (FYM); T4: PGPR 12.5 kg/ha ; T5: PGPR 25 kg/ha; T6: PGPR 7 kg/ha; T7: PGPR $12.5 \mathrm{~kg} / \mathrm{ha}+1 / 2 \mathrm{RDF}$; T8: PGPR $7 \mathrm{~kg} / \mathrm{ha}+1 / 2 \mathrm{FYM}$, were applied in this experiment. Wheat variety NL-971 was used. The results showed that the thousand grain weight showed significant result. The treatment with 10 t/ha FYM was found the best for spike length $(8.267 \mathrm{~cm})$, grains per five spikes $(160)$ and Thousand grain weight (49.28 g). Whereas, the highest yield (2.064 t/ha) was obtained with application of PGPR $7 \mathrm{~kg} / \mathrm{ha}+1 / 2$ FYM. The PH content was found the highest (5.453) with application of RDF. The maximum organic matter content (1.763) and N content $(0.1179 \%)$ were found with application of PGPR $12.5 \mathrm{~kg} / \mathrm{ha}$. Similarly, the highest phosphorus content $(75.83 \mathrm{mg} / \mathrm{kg}$ ) was found with application of PGPR7 kg/ha while the highest potassium content $(72.51 \mathrm{mg} / \mathrm{kg}$ ) was obtained with application of PGPR $25 \mathrm{~kg} / \mathrm{ha}$. Overall, there was positive impact of application of PGPR on wheat production.
\end{abstract}

Keywords: Grain yield, PGPR, wheat

Correct citation: Devkota, S., Rayamajhi, K., Yadav, D. R., \& Shrestha, J (2020). Effects of different doses of Plant-Growth-Promoting Rhizobacteria (PGPR) granules on wheat yield. Journal of Agriculture and Natural Resources, 3(2), 306-313.

DOI: https://doi.org/10.3126/janr.v3i2.32536

\section{INTRODUCTION}

The heavy use of agro chemicals in past few decades has been problematic to soil health and overall agro ecosystem. With increasing concerns on health and nutrition, the overall demand of enough good quality food is emerging (Kumar, 2010). The repeated over use of chemical fertilizers have adverse effects on soil quality, aggravate the soil organic matter, and accelerate the soil acidification ultimately reducing crop yield. (Li et al., 2017) Thus, the agricultural 
Journal of Agriculture and Natural Resources (2020) 3(2): 306-313

ISSN: 2661-6270 (Print), ISSN: 2661-6289 (Online)

DOI: https://doi.org/10.3126/janr.v3i2.32536

scientists have the responsibility of creating healthy agricultural system with minimum use of agrochemicals to avoid harmful risks. (Savci, 2012).

In a context of environmental protection and increased demand for chemical-free food products, increasing numbers of commercial biofertilizers have come onto the market in recent years, containing either single or associated PGPR strains or mycorrhizal fungi (Owen et al., 2015). Plant growth promoting Rhizobacterias (PGPR) are the microbial inoculants that promote plant growth directly and indirectly. The direct effects of PGPR bacteria on plants are the induction of plant growth by fixing $\mathrm{N}$ and synthesizing some vitamins and phytohormones such as auxins, cytokinins, and gibberllins (Saharan \& Nehra, 2011).

Additionally, they can inhibit ethylene synthesis of plants, improve uptake of nutrients, enhance stress resistance of the plant, and solubilize inorganic phosphate and mineralization of organic phosphate. The indirect effects of PGPRs are on plants are the prevention and reduction of the deleterious effects of pathogenic microorganisms by producing siderophores and antimicrobial secondary metabolites with fungicide and/or antibiotic properties (Saharan \& Nehra, 2011). However, the efficiency of application of PGPR depends upon a number of factors like soil mineral content, type of crop and its genotype, specific PGPR strain and its combination with the plant, competition with indigenous strains, environmental conditions and the growth parameters evaluated (Sahin et al., 2004; Cakmakci et al., 2007). Wheat (Triticum aestivum L.) being one of the staple cereals for one third of the world population provides the good amount of energy, renewable resources for food, feed and industrial raw material, protein and fibre source in human diet (Ramadoss et al., 2013).

The biological Nitrogen fixation is one among the various mechanisms that PGPR works for plant growth for example through diazotrophic association in wheat and subsequent addition of nitrogen to the ecosystem (Dobereiner,1996) contributing to the total nitrogen requirement of wheat (Islam et al., 2002; Iniguez et al., 2004;Veneiraki et al., 2011).Thus, the nitrogen fixing rhizobacteria provide an alternative source to inorganic fertilizers as the biological nitrogen fixation is considered to be a direct plant growth promoting trait.

Hence, the study was carried out to analyze the effects of various combinations of Plant growth promoting Rhizobacteria in granular form on the yield attributes and soil nutrient status of wheat crop.

\section{Experimental design and treatment detail}

Organic fertilizer product PGPR granules in various combinations were tested with wheat (Var NL-971) at Agriculture Research Station farm at Belachapi, Dhanusa in 2018. The experiment was laid out in Randomized Complete Block Design with eight treatments which were replicated thrice.

\section{Treatment details}

Wheat variety namely NL-971 was used in the experiment. This variety was received from National Wheat Research Program, Bhairahawa, Rupandehi, Nepal. The details of treatments was given in Table 1. 
Journal of Agriculture and Natural Resources (2020) 3(2): 306-313

ISSN: 2661-6270 (Print), ISSN: 2661-6289 (Online)

DOI: https://doi.org/10.3126/janr.v3i2.32536

Table 1. Treatment details used in the experiment

\begin{tabular}{ll}
\hline Treatment No. & Treatment details \\
\hline T1 & Control \\
T2 & Recommended dose of fertilizer $\left(100: 50: 50 \mathrm{~N}: \mathrm{P}_{2} \mathrm{O}_{5}: \mathrm{K}_{2} \mathrm{O} \mathrm{kg} / \mathrm{ha}\right)$ \\
T3 & $10 \mathrm{t} \mathrm{FYM} / \mathrm{ha}$ \\
T4 & PGPR Granules $12.5 \mathrm{~kg} / \mathrm{ha}$ \\
T5 & PGPR Granules $25 \mathrm{~kg} / \mathrm{ha}$ \\
T6 & PGPR Granules $7 \mathrm{~kg} / \mathrm{ha}$ \\
T7 & PGPR Granules $7 \mathrm{~kg} / \mathrm{ha}+1 / 2 \mathrm{RDF}$ \\
T8 & PGPR Granules $7 \mathrm{~kg} / \mathrm{ha}+1 / 2 \mathrm{FYM}$ \\
\hline
\end{tabular}

\section{Cultural practices}

The details of the treatments employed in the investigation are presented in Table 1. Seed sowing of wheat was done on November 28,2018 . The experimental plot size was $3 \times 2 \mathrm{~m}^{2}$ and was carried out in 24 plots. Seeds were sowed in $25 \mathrm{~cm}$ spacing in row and continuous spacing within the row. The recommended dose of fertilizers for wheat was 100:50:50 kg N, $\mathrm{P}_{2} \mathrm{O} 5$ and $\mathrm{K}_{2} \mathrm{O} / \mathrm{ha}$. All doses of $\mathrm{P}_{2} \mathrm{O} 5$ and $\mathrm{K}_{2} \mathrm{O}$ and half dose of $\mathrm{N}$ were applied as basal dose and rest half dose of $\mathrm{N}$ was applied as topdressing at 40 days after sowing. The required dose of all organic fertilizers was applied on the day of sowing before the seeds were sown. All necessary management was done as per the need and it was harvested. All necessary observations were collected as per the need. Soil sampling was done from all the plots after crop harvest and analyzed in the laboratory for $\mathrm{pH}$, organic matter, total $\mathrm{N}$, available $\mathrm{P}_{2} \mathrm{O}_{5}$ and $\mathrm{K}_{2} \mathrm{O}$.

\section{Data Collection}

Data was recorded for agronomic parameters of wheat: Average plant height $(\mathrm{cm})$, average spike length $(\mathrm{cm})$, average tillers per meter square, average grain yield $(\mathrm{t} / \mathrm{ha})$, Biomass $\left(\mathrm{kg} / \mathrm{m}^{2}\right)$, Grain per five spikes and thousand grain weight $(\mathrm{g})$ and soil parameters: $\mathrm{PH}$, Organic Matter (OM \%), Nitrogen(\%), Phosphorus (mg/kg) and Potassium ( $\mathrm{mg} / \mathrm{kg}$ ). and the parameters of okra: Plant height $(\mathrm{cm})$, fruit diameter $(\mathrm{mm})$, fruit length $(\mathrm{mm})$ and Yield $(\mathrm{t} / \mathrm{ha})$ along with soil parameters like PH,OM (\%), Nitrogen (\%),Phosphorus $(\mathrm{mg} / \mathrm{kg})$ and Potassium $(\mathrm{mg} / \mathrm{kg})$ were recorded in Soil testing Laboratory of National Soil Science Research Division, Khumaltar.

\section{Statistical Analysis}

All agronomic parameters of respective crops were recorded and entered in MS-Excel. Data validation was carried out in MS-Excel 2010 version. After cleaning, the data were subjected to one-way ANOVA analysis using RCBD model in GenStat5 3.2 version and Star. All the significant means were further subjected to Post-Hoc analysis by Duncan's Multiple Range Test at 5\% level of significance (Shrestha, 2019).

\section{RESULTS AND DISCUSSION}

\section{Crop parameters}

The Application of FYM showed the highest average spike length $(8.267 \mathrm{~cm})$. There was no significant difference on average plant height, and average tiller $/ \mathrm{m}^{2}$ on wheat with application of PGPR (granules). The highest plant height $(88.27 \mathrm{~cm}$ ) was recorded from PGPR $7 \mathrm{~kg} / \mathrm{ha}$ and highest average tiller $/ \mathrm{m}^{2}\left(267.7\right.$ tiller $\left./ \mathrm{m}^{2}\right)$ was recorded from control. No significant difference was observed by application of PGPR (granules) on average grain yield and 
Journal of Agriculture and Natural Resources (2020) 3(2): 306-313

ISSN: 2661-6270 (Print), ISSN: 2661-6289 (Online)

DOI: https://doi.org/10.3126/janr.v3i2.32536

biological yield of wheat. Application of PGPR $7 \mathrm{~kg} / \mathrm{ha}+1 / 2 \mathrm{FYM}$ gives the highest grain yield $(2.064 \mathrm{t} / \mathrm{ha})$ whereas the highest biological yield $\left(0.5292 \mathrm{~kg} / \mathrm{m}^{2}\right)$ was obtained from control.

Table 2. Effect of PGPR (granule) on Harvesting Parameter of Wheat, at Belachapi, Dhanusa, 2075

\begin{tabular}{|c|c|c|c|c|c|c|c|c|}
\hline S.N. & Treatments & $\begin{array}{l}\text { Average } \\
\text { plant } \\
\text { height } \\
(\mathrm{cm})\end{array}$ & $\begin{array}{l}\text { Average } \\
\text { Spike Length } \\
(\mathrm{cm})\end{array}$ & $\begin{array}{l}\text { Average } \\
\text { Tiller/ m2 }\end{array}$ & $\begin{array}{l}\text { Average } \\
\text { Grain } \\
\text { Yield } \\
\text { (t/ha) } \\
\end{array}$ & $\begin{array}{l}\text { Biomass } \\
(\mathrm{kg} / \mathrm{m} 2)\end{array}$ & $\begin{array}{l}\text { Grain per } \\
5 \text { spike }\end{array}$ & $\begin{array}{l}\text { Thousand } \\
\text { Grain } \\
\text { Weight (g) }\end{array}$ \\
\hline 1. & Control & 88.2 & 7.467ab & 267.7 & 1.224 & 0.5292 & 136.3 & $47.68 \mathrm{ab}$ \\
\hline 2. & $\mathrm{RDF}$ & 82.2 & $7 \mathrm{ab}$ & 170.3 & 1.798 & 0.3525 & 140.7 & $48.5 \mathrm{ab}$ \\
\hline 3. & $\begin{array}{l}10 \mathrm{t} \mathrm{FYM} / \mathrm{ha} \\
\mathrm{t} / \mathrm{ha}\end{array}$ & 86.8 & $8.267 \mathrm{a}$ & 190 & 1.792 & 0.4617 & 159.3 & $49.28 \mathrm{a}$ \\
\hline 4. & $\begin{array}{l}\text { PGPR } 12.5 \\
\mathrm{~kg} / \mathrm{ha}\end{array}$ & 82.47 & $7.333 \mathrm{ab}$ & 171.7 & 1.315 & 0.3525 & 139.7 & 47.61ab \\
\hline 5. & $\begin{array}{l}\text { PGPR } 25 \\
\mathrm{~kg} / \mathrm{ha}\end{array}$ & 85.4 & 7.467ab & 210 & 1.793 & 0.4608 & 141.3 & $44.62 b c$ \\
\hline 6. & $\begin{array}{l}\text { PGPR } 7 \\
\mathrm{~kg} / \mathrm{ha}\end{array}$ & 81.13 & 7.333ab & 172 & 1.288 & 0.3417 & 122.7 & 46.31ab \\
\hline 7. & $\begin{array}{l}\text { PGPR } 7 \\
\mathrm{~kg} / \mathrm{ha}+1 / 2 \\
\mathrm{RDF}\end{array}$ & 83.4 & $6.533 b$ & 231.7 & 1.2 & 0.3367 & 134.7 & $45.5 \mathrm{abc}$ \\
\hline 8. & $\begin{array}{l}\text { PGPR } 7 \\
\mathrm{~kg} / \mathrm{ha}+1 / 2 \\
\text { FYM } \\
\end{array}$ & 88.27 & 7.733ab & 227 & 2.064 & 0.5158 & 121.3 & $42.18 \mathrm{c}$ \\
\hline & $\begin{array}{l}\text { SEM } \\
\text { P value } \\
\text { CV \% } \\
\text { LSD }(0.05)\end{array}$ & $\begin{array}{l}3.206 \\
0.232 \\
4.6 \\
6.877 \\
\end{array}$ & $\begin{array}{l}0.673 \\
0.400 \\
11.2 \\
1.444 \\
\end{array}$ & $\begin{array}{l}56.6 \\
0.612 \\
33.8 \\
121.4 \\
\end{array}$ & $\begin{array}{l}0.404 \\
0.283 \\
31.7 \\
0.867 \\
\end{array}$ & $\begin{array}{l}0.1309 \\
0.616 \\
38.3 \\
0.2808 \\
\end{array}$ & $\begin{array}{l}16.17 \\
0.421 \\
14.5 \\
34.67 \\
\end{array}$ & $\begin{array}{l}1.663 \\
0.015 \\
4.4 \\
3.566 \\
\end{array}$ \\
\hline
\end{tabular}

$C V=$ coefficient of variation, SEM= Standard Error of Mean, SE $=$ Standard Error, LSD= Least Significant Difference. $R D F=$ Recommended Dose of Fertilizer, PGPR= Plant Growth Promoting Rhizobacteria, FYM= Farm Yard Manure

Application of PGPR (granules) organic fertilizer produce significant effect on the thousand grain weight but there is no significant difference in the grain per spike. The highest thousand grain weight (49.28 g) and the highest grain per 5 spike (159.3) was obtained from the application of $10 \mathrm{~kg} / \mathrm{ha}$ FYM.

\section{Soil parameters}

Similarly, there was no significant difference among organic matter, $\mathrm{N}$ content, $\mathrm{K}$ content and Phosphorous content in different treatment combinations but there was significant influence in soil pH improvement with the application of PGPR (granules) together with NPK.

The highest soil $\mathrm{pH}$ (5.453) was obtained from the application of RDF. The lowest $\mathrm{pH}$ (5.223) was obtained from PGPR $25 \mathrm{~kg} / \mathrm{ha}$. Soil N content was the highest $(0.1179 \%)$ and the highest organic matter content $(1.763 \%$ ) was obtained the application of PGPR (granules) $12.5 \mathrm{~kg} / \mathrm{ha}$. $\mathrm{K}$ content increases as the PGPR (granules) was added with $25 \mathrm{~kg} / \mathrm{ha}$. Soil phosphorous availability increases by PGPR (granules) while applying with $7 \mathrm{~kg} / \mathrm{ha}$. 
Journal of Agriculture and Natural Resources (2020) 3(2): 306-313

ISSN: 2661-6270 (Print), ISSN: 2661-6289 (Online)

DOI: https://doi.org/10.3126/janr.v3i2.32536

Table 3. Effect of PGPR (granules) on soil pH, organic matter, nitrogen, phosphorous and potassium content after harvest of wheat 2075

\begin{tabular}{llccccc}
\hline S.N. & Treatments & PH & OM \% & N \% & P mg/kg & $\mathrm{K} \mathrm{mg} / \mathrm{kg}$ \\
\hline 1 & Control & $5.277 \mathrm{ab}$ & 1.337 & 0.0912 & 68.62 & 55.86 \\
2 & RDF & $5.453 \mathrm{a}$ & 1.552 & 0.1047 & 70.21 & 49.8 \\
3 & $10 \mathrm{t} \mathrm{FYM/ha}$ & $5.393 \mathrm{ab}$ & 1.394 & 0.0948 & 74.12 & 61.92 \\
4 & PGPR 12.5 kg/ha & $5.3 \mathrm{ab}$ & 1.763 & 0.1179 & 73.39 & 52.39 \\
5 & PGPR 25 kg/ha & $5.223 \mathrm{~b}$ & 1.537 & 0.1037 & 73.39 & 72.51 \\
6 & PGPR 7 kg/ha & $5.253 \mathrm{~b}$ & 1.521 & 0.1027 & 75.83 & 44.28 \\
7 & PGPR 7 kg/ha + 1/2 RDF & $5.267 \mathrm{ab}$ & 1.636 & 0.1099 & 74.49 & 70.59 \\
8 & PGPR 7 kg/ha +1/2 FYM & $5.367 \mathrm{ab}$ & 1.682 & 0.1129 & 74.36 & 68.49 \\
\hline & SEM & 0.0785 & 0.2522 & 0.01584 & 7.29 & 17.87 \\
& P value & 0.121 & 0.723 & 0.723 & 0.975 & 0.681 \\
& CV \% & 1.8 & 19.9 & 18.5 & 12.2 & 36.8 \\
& LSD & 0.1684 & 0.5410 & 0.03397 & 15.64 & 38.32
\end{tabular}

$C V=$ coefficient of variation, SEM= Standard Error of Mean, SE= Standard Error, LSD= Least Significant Difference. $R D F=$ Recommended Dose of Fertilizer, PGPR= Plant Growth Promoting Rhizobacteria, FYM= Farm Yard Manure

\section{Response of various treatment combinations on Yield attributes}

The yield attributes of wheat viz. grain per five spikes, thousand grain weight, biomass had different responses(Figure1). The average grain yield was the highest at PGPR $7 \mathrm{~kg} / \mathrm{ha}$ and half FYM dose application followed by PGPR $25 \mathrm{~kg} / \mathrm{ha}$ and RDF. However, biomass was similar in both control as well as (PGPR $7 \mathrm{~kg} / \mathrm{ha}$ and half dose FYM) condition. As clearly seen in graph below, the grains per 5 spikes and thousand grain weight have more or less similar responses in various treatment combinations.

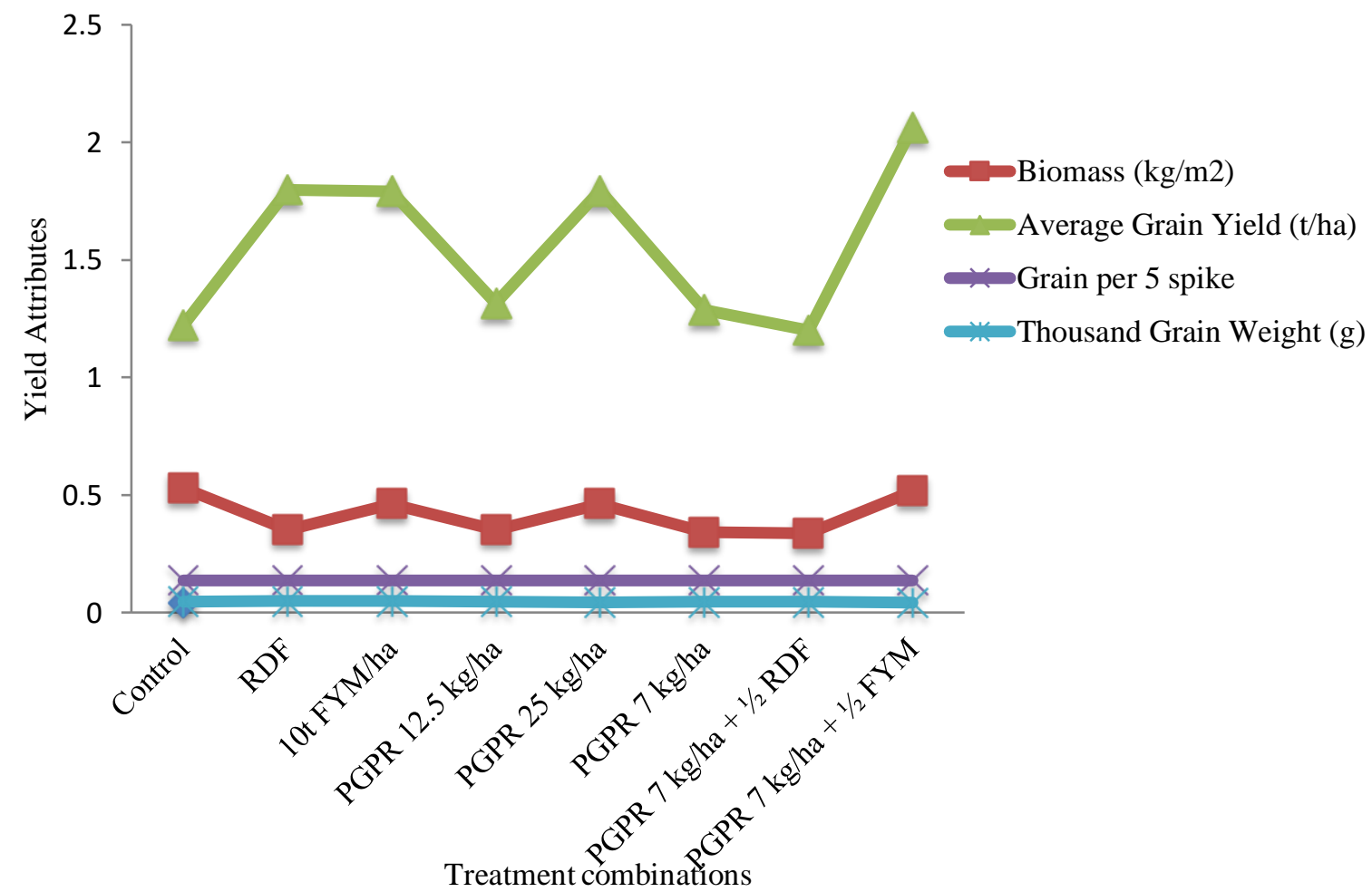

Figure1. Graphical representation of various treatment responses on Yield attributes. 
Journal of Agriculture and Natural Resources (2020) 3(2): 306-313

ISSN: 2661-6270 (Print), ISSN: 2661-6289 (Online)

DOI: https://doi.org/10.3126/janr.v3i2.32536

\section{Effect different treatment combinations on Nitrogen, Phosphorus and Potassium contents}

The application of PGPR on various doses of combination affected the nitrogen, phosphorus and potassium contents of the soil (Figure2). The nitrogen content was the highest at 12.5 $\mathrm{kg} / \mathrm{ha}$ and more or less similar in several does, while the phosphorus content was highest at $7 \mathrm{~kg} / \mathrm{ha}$, with higher contents in all combinations than the control condition.However, the potassium content showed more variable response to different doses. As the highest content was seen in $25 \mathrm{~kg} / \mathrm{ha}$ dose followed by $7 \mathrm{~kg} / \mathrm{ha}$ with half RDF and $7 \mathrm{~kg} / \mathrm{ha}$ with half FYM. The lowest content of potassium was found at $7 \mathrm{~kg} / \mathrm{ha}$ followed by RDF compared to control, which contrasts with phosphorus content which was the highest at $7 \mathrm{~kg} / \mathrm{ha}$ dose.

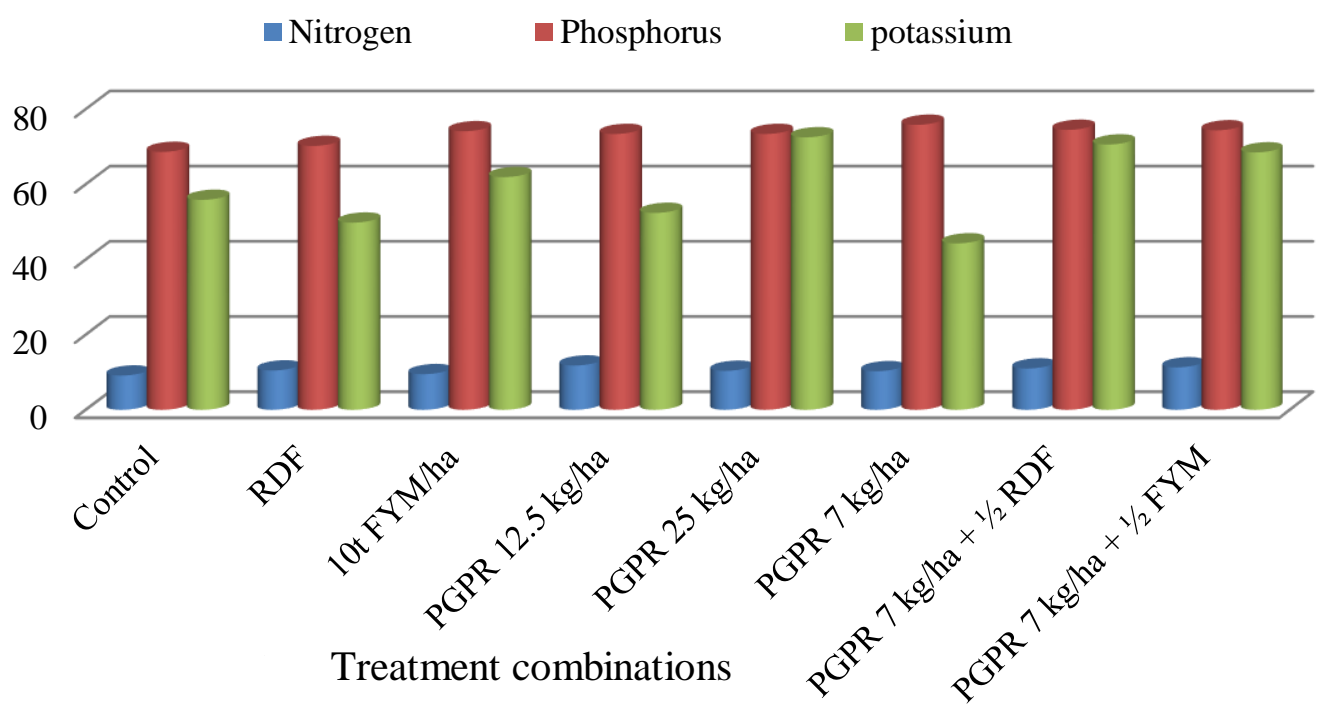

Figure 2. Effects of various treatment combinations on nitrogen, phosphorus and potassium contents on soil.

\section{DISCUSSION}

Our investigation showed that the application of the PGPR granules in combination with 10 $\mathrm{kg}$ FYM per hectare is found to be most beneficial in terms of yield attributing traits. As the highest spike length, grains per spike and thousand grain weight was found maximum when PGPR is applied with 10kg FYM per hectare. Similarly, average grain yield is highest with PGPR $7 \mathrm{~kg}$ and FYM $0.5 \mathrm{~kg}$ per hectare. Such response of yield attributes is also supported by various studies. The various beneficial rhizobacteria associated with cereals have positive beneficial effects on growth and yield of wheat at various environments (Turan et al., 2010). The application of PGPR granules increases the shoot length, root length, shoot and root dry weight, grain weight per spike, shoot and root $\mathrm{N}$ content and $\mathrm{N}$ content of the seedlings.(Saubidet et al., 2002). In wheat, several rhizobacteria associated plant growth promoters have been reported to increase the grain yield and grain protein concentration of the wheat (Majeed et al., 2015; Tiwari et al, 2011). Despite the promising features from agronomic efficiency and crop yield perspective, the key bottleneck for the commercial use of PGPRs is their varying performance under field conditions: the results obtained in a field are not always similar to those of laboratory (Smyth et al., 2011) which calls for immediate further research on the agricultural use of these PGPRs.The application of PGPR granules 
Journal of Agriculture and Natural Resources (2020) 3(2): 306-313

ISSN: 2661-6270 (Print), ISSN: 2661-6289 (Online)

DOI: https://doi.org/10.3126/janr.v3i2.32536

shows great impact on soil properties as well. Our study suggests the increment in Organic matter, Nitrogen as well as Phosphorus content than under control condition. This would automatically reduce the use of the higher amount of Nitrogen and Phosphorus fertilizers. The usage of PGPR could significantly reduce $\mathrm{P}$ and $\mathrm{N}$ fertilizer application without any reduction in wheat yield-related parameters (Saber et al., 2012) while inoculation was effective with inorganic fertilizer doses, its positive impact decreased with increasing rates of fertilizer application. Our findings could improve the sustainability of the whole system, as it will minimize the use of inorganic fertilizers which are major causes of global warming and climate change (Rizwaan et al., 2019). Our study main aim was to reduce the chemical fertilizers by utilizing potential wheat rhizospheric bacteria as inoculants, and all results showed that PGPR plays an important role and is useful to reduce the rate of inorganic fertilizers, mainly because it makes nutrients available.

\section{CONCLUSION}

The application of PGPR (granules) in various combinations have significant effects on spike length and thousand grain weight in wheat while the Other crop parameters like plant height, biological yield, tiller number, grain yield have variable effects. The best treatment combination was found to be PGPR with 10kg/ha FYM for both spike length and grains per five spikes. Thousand grain weight was found higher in both RDF and PGPR with $10 \mathrm{~kg} / \mathrm{ha}$ FYM in comparison to control condition. While the average yield per hectare was highest in PGPR $7 \mathrm{~kg} / \mathrm{ha}$ with half dose of FYM.There was significant increment in soil parameters like $\mathrm{PH}$, Organic matter, Nitrogen content, Phosphorus content and potassium contents due to various combinations of PGPR with other fertilizers. The PH content was found highest at RDF. The OM content as well as N content was found maximum at PGPR $12.5 \mathrm{~kg} / \mathrm{ha}$ dose. Similarly, the phosphorus content was found to be highest at $7 \mathrm{~kg} / \mathrm{ha}$ PGPR while the potassium content was highest at $25 \mathrm{~kg} / \mathrm{ha}$ PGPR. Hence, application of PGPR in various combinations was found to have significant impact on wheat production, as the paramount dose of harmful chemical fertilizers can be reduced efficiently with adding double benefits increasing crop quality and preserving soil health.

\section{ACKNOWLEDGEMENT}

The authors would like to acknowledge Nepal Agricultural Research Council for funding this research.

\section{Authors' Contributions}

S. Devkota made the study conception and design, analysis and interpretation of data, drafting of the manuscript. K. Rayamajhi and D. Yadav contributed for acquisition of data of experiment. J. Shrestha made critical revision of the final manuscript.

\section{Conflict of author}

The authors declare that there is no conflict of interest.

\section{REFERENCES}

APP. (1995). Nepal Agriculture Perspective Plan, APROSC and JMA Inc. National Planning Commission Secretariat, Singh Durbar, Kathmandu Nepal, p.66.

Atreya, P.N., \& Kafle, A. (2016). Production, practice, market and value chain study of organic apple of Jumla. Journal of Agriculture and Environment, 17, 11-23. 
Journal of Agriculture and Natural Resources (2020) 3(2): 306-313

ISSN: 2661-6270 (Print), ISSN: 2661-6289 (Online)

DOI: https://doi.org/10.3126/janr.v3i2.32536

Bhat, Z.A., Akther, F.A., Ganaie, A.Q., Rehman, H.U., Dar, N.A., \& Gill R.K. (2017). Nutrient Status of Grape Orchard Soils of Jammu and Kasmir, India. MOJ Ecology and Environmental Science, 2(5), 1-8. DOI: 10.15406/mojes.2017.02.00036

Brady, N. (2000). The Nature and Properties of Soils (Tenth ed.). New York: Macmillan Publishing Company.

Bremner, J., \& Mulvaney, C. (1982). Total Nitrogen. In Page, A., Miller, R., \& Keeny, D. (eds.), Methods of Soil Analysis (pp. 1119-1123). Madison: American Society of Agronomy and Soil Science Society of America.

FAOSTAT. (2020). Crops. Retrieved September 18, 2020, from www.fao.org/faostat/en.

Ganai A.Q., Dar M.A., Chesti M. H., Bhat Z.A., Khanday M., \& Dar N.A. (2018). Macronutrients status of apple (cv. red delicious) orchard soils of Jammu and Kashmir India. International Journal of Chemical Studies, 6(2), 3314-3319.

Ganorkar, R.P., \& Chinchmalatpure, P.G. (2013). Physicochemical assessment of soil in Rajura Bazar in Amaravati district of Maharastra (India). International Journal of Chemical, environmental and Pharmaceutical Research, 4(2\&3), 46-49.

Jackson, M. (1967). Soil Chemical Analysis. New Delhi: Prentice Hall of India Pvt. Ltd.

Khanday, M., Wani, J.A., Ram, D., \& Kumar S. (2018). Depth wise distribution of available nutrients of soils of horticultural growing areas of ganderbal district of Kashmir valley. Journal of Pharmacognosy and Phytochemistry, 7(1), 19-22.

Kopytko, P., Karpenko, V., Yakovenko, R., \& Mostoviak, I. (2017). Soil fertility and productivity of apple orchard under a long-term use of different fertilizer systems. Agronomy Research, 15(2), 444-455.

Olsen, S., Cole, C., Watanbe, F., \& Dean, L. (1954). Estimation of available phosphorus in soils by extraction with sodium bicarbonate. Washington DC: Government Printing Office.

Sallato, B., DuPont, T., \& Granatatein, D. (2019). Tree fruit soil fertility and plant nutrition in cropping orchards in Central Washington. Washington State University. Retrieved August 28, 2020, from http://treefruit.wsu.edu/orchard-management/soilsnutrition/fruit-tree-nutrition/.

Sartaj, A.W., Najar, G.R., Bilal, A. P., Akhter, F., \& Chand, S. (2017). Altidunal and depthwise variation of soil Physico- chemical properties and available nutrients of Pear orchards in Jammu and Kasmir, India. Chemical Science Review and letters, 6(23), $1638-1645$.

Shrestha, J. (2019). P-Value: A True Test of Significance in Agricultural Research. Retrieved August 18, 2020, from https://www.linkedin.com/pulse/p-value-test-significanceagricultural-research-jiban-shrestha/. DOI: http://doi.org/10.5281/zenodo.4030711

Soil Science Division. (2019). Objective of soil analysis and method of sampling. 12p.

Walkley, A., \& Black, I. (1934). An examination of direct method for determining organic matter and the proposed modification of the chromic acid titration method. Soil Science Society of America Journal, 37, 29-38.

Yara. (2020). Apple Agronomic Principal. Retrieved August 28, 2020, from https://www.yara.us/crop-nutrition/apple/agronomicprinciples/\#: :text=Apples\%20prefer\%20a\%20slightly\%20acidic,by\%20incorporati ng\%20lime\%20before\%20planting. 